\title{
Using Microsoft Quiz and Mobile Exam Applications to Improve Teacher Competence in Online Learning in the New Normal Era
}

\author{
Sakroni ${ }^{1}$, Siswanto ${ }^{2}$ \\ sakroni@staff.uns.ac.id, sis.mipa@staff.uns.ac.id
}

\begin{abstract}
The pandemic that came suddenly resulted in teachers not having sufficient preparation in adapting to distance learning by utilizing information technology. The problem found is that teacher's literacy is still lacking in the use of the application to support distance learning, including the use of applications for learning evaluations. Therefore, training in using the Microsoft Quiz application and mobile exam is required for teachers. This article aims to describe the use of the Microsoft Quiz application and the mobile exam as media for assessing and evaluating distance learning. The research method used was a descriptive qualitative method with the ADDIE model of learning design. Based on this study's results, it was revealed that this learning design could be applied to training in the use of the Microsoft Quiz application and the mobile exam. The research stage included analysis, design, development, implementation, and evaluation. The study's results showed that the training in the use of the Microsoft quiz and mobile exam applications could improve teacher competence in online learning in the new normal era.
\end{abstract}

Keywords: $\quad$ online learning, microsoft quiz, new normal

Abstrak: $\quad$ Pandemi yang datang secara tiba-tiba mengakibatkan para guru tidak mempunyai persiapan yang cukup dalam melakukan adaptasi pembelajaran jarak jauh dengan memanfaatkan teknologi informasi. Permasalahan yang ditemukan adalah literasi guru dalam pemanfaatan aplikasi yang mendukung pembelajaran jarak jauh termasuk pemanfaatan aplikasi untuk evaluasi pembelajaran masih kurang. Oleh karena itu, pelatihan pemanfaatan aplikasi microsoft quiz dan mobile exam diperlukan bagi guru. Penulisan artikel ilmiah ini bertujuan untuk mendeskripsikan tentang pemanfaatan aplikasi microsoft quiz dan mobile exam sebagai media untuk penilaian dan evaluasi pembelajaran jarak jauh. Metode penelitian yang digunakan adalah kualitatif deskriptif dengan menggunakan desain pembelajaran model ADDIE. Berdasarkan hasil kajian, diketahui bahwa desain pembelajaran ini dapat diterapkan pada pelatihan pemanfaatan aplikasi microsoft quiz dan mobile exam. Tahap penelitian meliputi analysis, design, development, implementation, evaluation. Hasil dari penelitian menunjukan bahwa pelatihan pemanfaatan aplikasi microsoft quiz dan mobile exam dapat meningkatkan kompetensi guru dalam pembelajaran daring di era new normal.

Kata Kunci: $\quad$ microsoft quiz. pembelajaran daring, new normal

Submitted: December 2020 $\quad$ Reviewed: January $2021 \quad$ Accepted: March $2021 \quad$ Published: March 2021

1 Universitas Sebelas Maret

2 Universitas Sebelas Maret 
T he era of the industrial revolution 4.0 was marked by the rapid development of science and technology, especially information and communication technology. A result of these developments brought great changes in all sectors of life, including the education sector. The education's characteristic in the industrial era 4.0 is that it uses a lot of digital technology (Cyber System) in the learning process, which is not limited by time and space and can be accessed anytime and anywhere (Surani, 2019). Education in the industrial era 4.0 has changed the way of learning, thinking patterns, and the way students and teachers act in developing innovation and creativity in various fields. It is a big challenge for educators, both lecturers and teachers, continuously to improve their competence to keep up with science and technology developments. As Jack Ma (2018) said in the World Economic Forum, the world of education is currently experiencing big challenges; if the teacher does not change the way of teaching, they will have big difficulties later (Ma, 2018). Therefore, according to Shintya Gugah quoted on the Indonesian Ombudsman page, there are at least four competencies that a teacher must-have in the era of the industrial revolution 4.0, namely: 1) critical thinking and problem-solving skills, 2) communication and collaboration skills, 3) creative and innovative thinking skills, and 4) have the technology and information literacy (Gugah, 2020).

Simultaneously, with the incessant use of information and communication technology to improve Indonesia's quality of learning came the coronavirus outbreak. Since the end of 2019, the World Health Organization (WHO) has designated the coronavirus or COVID-19 outbreak as a global pandemic, which has attacked almost all countries in the world, including Indonesia. The COVID-19 pandemic in Indonesia began in March 2020 after several Indonesian citizens contracted the virus. To break the chain of coronavirus spread, the Indonesian government issued a social distancing policy with largescale social restrictions (PSBB). Almost all sectors of life, including economic, social, industrial, tourism, and education sectors, have been affected by the adverse effects of COVID-19 (Dewi, 2020). Some activities must be adapted to new habits, better known as the new normal era, including educational activities ranging from pre-school to college. The Ministry of Education and Culture responded by issuing a study from home policy under Circular Number 4 of 2020 the Minister of Education and Culture regarding the implementation of education policies in the emergency period of the coronavirus disease (COVID-19) spread, which was issued on March 24, 2020 (Mendikbud, 2020). It was reinforced by the Circular of the Secretary-General of the Ministry of Education and Culture Number 15 of 2020 concerning guidelines for implementing learning from home (BDR) during the COVID-19 disaster emergency in Indonesia (Kemendikbud, 2020). From these circulars, teachers must facilitate online, offline, and a combination of both during the COVID-19 pandemic, according to the learning facilities' conditions and availability.

In most schools, especially elementary and secondary levels, this pandemic situation has hindered the teaching and learning process, usually face-to-face (offline). Currently, teachers are forced to implement distance learning by utilizing information and communication technology. The sudden outbreak of the COVID-19 pandemic has made teachers unprepared to conduct distance learning (online). Based on Jehamun's analysis cited by Rina Mutaqina and Taufik Hidayatullah, online learning is indeed a dilemma for teachers and students. On the one hand, the learning process must run; on the other hand, various obstacles accompanied the implementation process: 1) many teachers still had limitations in terms of access to and use of their devices, and not all teachers could operate and take advantage of their sophisticated gadgets; 2) independent learning at home could not be fully implemented; 3) assignments and homework given by the teacher was burdensome for students; 4) not all students had a device (handphone); 5) online learning was constrained by signals (Mutaqinah, 2020). Meanwhile, according to Dr. Gogot Suharwoto, Indonesian education currently faces several real challenges that must be addressed, including 1) technological imbalances between schools in big cities and remote areas, 2) limited teacher competence in the use of learning applications, 3) limited 
resources for the use of educational technology, such as internet and quotas, and 4) teacher-studentparent relations in online learning that are not yet integral (Suharwoto, 2020).

According to the Professor of the University of Applied Science and Arts, Hannover, Germany, and Senior Experten Services (SES) Germany, Prof. Dr. Gerhad Fortwengel quoted by lka, the current COVID-19 pandemic can actually accelerate education 4.0. and become a great catalyst that spurs the world of education by encouraging schools and colleges to make more use of information technology in distance learning activities (Ika, 2020). Therefore, now is the right time to make distance learning a transformation of Indonesia's education world. The consequence is that teachers must improve competence, especially in the use of distance learning applications, including applications for evaluating student learning outcomes.

In the current new normal era, learning evaluation and assessment cannot be carried out as usual by gathering in class, using paper, and directly supervised by the teacher. Learning evaluation and assessment must be adapted by utilizing information technology so that teachers can monitor the achievement of learning objectives. Evaluation is part of the teaching and learning process, which, overall, its activities cannot be separated from teaching activities. According to R.J Stiggins, evaluation and assessment are used as benchmarks and aim to measure the achievement of learning objectives (R. J. Stiggins, 1994). Meanwhile, according to Ralph Tyler in Arikunto (2012), evaluation is a process of collecting data to determine to what extent, in what way, and how educational goals have been achieved (Arikunto, 2012). If the assessment is not carried out, the teacher cannot know the learning's success. In Permendiknas (Regulation of the Minister of National Education) No. 16 of 2007, teachers must have pedagogical competence, namely teachers must be able to carry out assessment and evaluation of learning processes and outcomes and must be able to utilize technology and information for the learning's benefit (Mendiknas, 2007). Based on these regulations, teachers must carry out learning assessments and evaluations in all conditions because evaluation is part of the teaching and learning process whose overall activities cannot be separated from teaching activities (Rachmawati \& Kurniawati, 2020).

On the other hand, almost all students today already have smartphones with multi-functional features close to a personal computer's (PC) capabilities and at a relatively cheaper price than a PC or laptop's price. More and more people who own and use smartphones open up opportunities to use mobile technology devices in the education world. Various innovations and creativities have been made to take advantage of mobile technology with supporting applications for educational purposes (Ardiansyah \& Nana, 2020). There is great potential in using mobile devices to change the way of learning, from traditional classrooms to be more interactive and engaging (Shen, Wang, \& Pan, 2008 in Zydney, 2016). It allows teachers to teach without being constrained by time and place and allows learning to continue after class ends or outside the classroom, where learning occurs naturally (Huang, Lin, \& Cheng, 2010 in Zydney, 2016) (Zydney \& Warner, 2016). Applications to support smartphone capabilities are currently emerging, one of which is the Microsoft form/quiz and mobile exam, which teachers can use to conduct online learning evaluations and assessments.

Utilizing smartphones with the Microsoft quiz and mobile exam applications for online exams is not easy, especially for teachers who are not familiar. In this case, several conditions must be met: 1) teachers and students must have easy access to technological devices and internet access, 2) available digital teaching materials that are easy for teachers and students to understand, and 3) teachers and students must be skilled in using technology and resources to help students achieve academic standards (Sarjono, 2013). Apart from these three things, teachers must also be skilled in making quizzes based on Microsoft quizzes. The following data were obtained from the survey results held in June 2020 with 109 mathematics teachers as respondents in Sragen Regency Junior High School after implementing a home learning program due to the COVID-19 pandemic. 1) Of the media 
used to assign assignments to students while studying from home, $82.6 \%$ of teachers used WhatsApp. 2) Regarding the means/media used to give students tests while studying from home, $44 \%$ of teachers utilized WhatsApp; some used google forms, paper, Microsoft quizzes, Moodle, and Edmodo. 3) Concerning teachers' ability to use information and communication technology to support online learning, $56 \%$ of teachers said it was enough, $28 \%$ said it was not good, and only $16 \%$ of teachers said it was good.

Based on the description above, to solve the problem according to the Circular of the Minister of Education and Culture of the Republic of Indonesia so that students learn from home, how can teachers increase their competence by utilizing media or information technology to support the distance teaching and learning process, especially the evaluation and assessment process using smartphone media with supporting applications?

\section{RESEARCH METHODS}

Research on the use of the Microsoft Quiz and Mobile Exam applications to improve teacher competence in online learning in the new normal era was conducted in June - August 2020. The target or respondents involved were junior high school mathematics teachers, both public and private, in Sragen Regency, Central Java. This research was part of community service activities organized by the Mathematics Study Program, Faculty of Mathematics and Natural Sciences, Universitas Sebelas Maret Surakarta (FMIPA UNS). It was fully supported through the Research Group Grant Scheme (HGRUNS) program with the leading field of Information, and Communication Technology oriented towards education.

The research method used was descriptive qualitative with data collection methods through observation, surveys, and interviews. To provide good results according to current needs, the authors employed the ADDIE model of learning design (Analysis, Design, Development, Implementation, Evaluation) (Carey, 2015). The ADDIE model of learning design was developed by Dick and Carey in 1978. This model is very relevant and easy to apply in the development of current education and training programs.

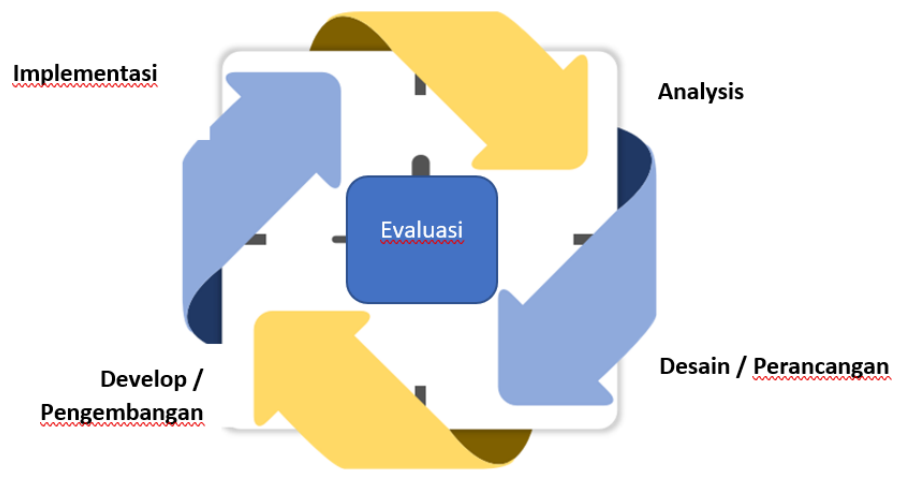

Figure 1. The ADDIE model cycle adapted from the ADDIE model

The research stages of using the Microsoft quiz and mobile exam applications to improve teacher competence in online learning in the new normal era were divided into several stages, as follows:

\section{Analysis stage}

At this stage, a needs assessment, problem identification, and task analysis were carried out. The needs analysis results obtained the profile and level of ICT literacy possessed by potential participants, 
identifying gaps, identifying needs, and identifying supporting facilities and infrastructure for online learning.

\section{Design stage}

At this stage, a form of utilization of Microsoft quiz and mobile exams was designed to improve the competence of mathematics teachers in online learning in the new normal era according to the needs analysis results, including 1) determining activity objectives and learning objectives, 2) determining appropriate learning strategies in the new normal era, 3) preparing lesson plans (RPP) and syllabus, and 4) making learning modules in accordance with the lesson plans and syllabus.

\section{Development stage}

Development is the process of making a design a reality (Sugiyono, 2017). This stage was developed based on previously made learning designs. Development activities included identifying, creating, buying, or modifying the teaching materials designed. Besides, it also determined the learning methods, the media used, and the learning strategies used according to the situations and conditions. At this stage, a trial of the application to be used and the participant's Office 365 account was also carried out.

\section{Implementation stage}

The implementation stage is the stage of implementing the learning system in accordance with the analysis results, design, and development that had been done previously. At the implementation stage, the use of the Microsoft quiz and mobile exam applications to improve math teacher competence in online learning in the new normal era comprised: 1) delivering training materials to junior high school math teachers online through video conferencing facilities at Office $365 ; 2$ ) online mentoring and guidance through the participant group (WhatsApp group) during the training; 3 ) providing solutions to address the ICT literacy gap between participants; 4) guaranteeing and ensuring that at the end of the training, participants had the necessary knowledge, skills, and competencies in the new normal era.

\section{Evaluation and follow-up stage}

The evaluation stage is the stage to measure the learning's effectiveness and efficiency (G.Muruganantham, 2015). At this stage, an implementation evaluation of the Microsoft quiz and mobile exam application was conducted to improve teacher competence in online learning in the new normal era through training, mentoring, and guidance by providing posttests and questionnaires to the mathematics teachers participating in the training.

\section{RESULTS AND DISCUSSIONS}

\section{Needs Analysis}

Preliminary research was carried out after the even semester learning ended. The questionnaire was given to 109 junior high school mathematics teachers in Sragen Regency in June 2020 to obtain an overview of ICT use in the online teaching and learning process during the home learning program. The questionnaire results are shown as follows: 

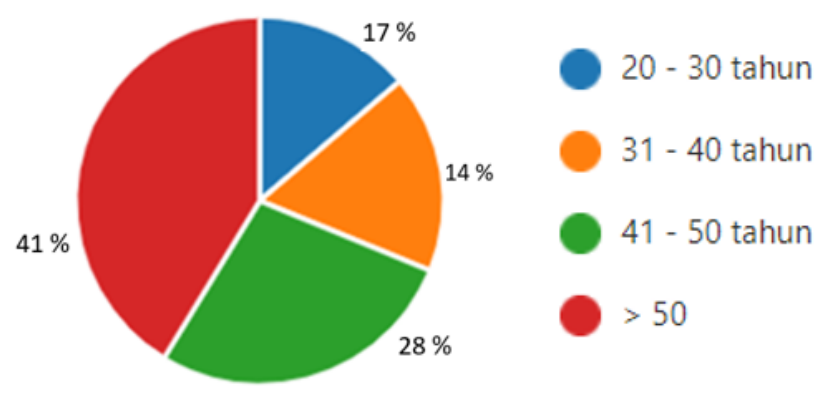

Figure 2: Distribution of respondents by age

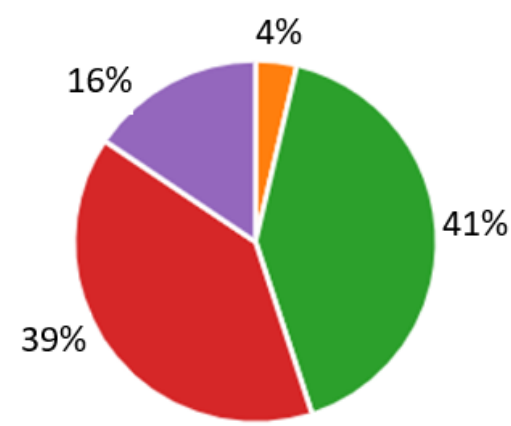

\begin{tabular}{lc} 
Sangat Baik & 0 \\
Baik & 4 \\
Cukup Baik & 45 \\
Kurang Baik & 43 \\
\hline
\end{tabular}

Figure 3: Teacher ICT Literacy for online material delivery

From Figure 2 above, regarding the age of junior high school math teachers in Sragen Regency, $69 \%$ of the teachers were over 40 years old, and only 31\% were between the ages of 20-40 years. Meanwhile, in Figure 3, concerning the teachers' ICT literacy to deliver mathematics subject matter, only $4 \%$ said it was good, $41 \%$ said it was good enough, while the rest $55 \%$ said it was lacking. This study did not examine the relationship between age and the teachers' literacy/competence level in ICT; however, the data showed a correlation between age and the teachers' ICT competence.
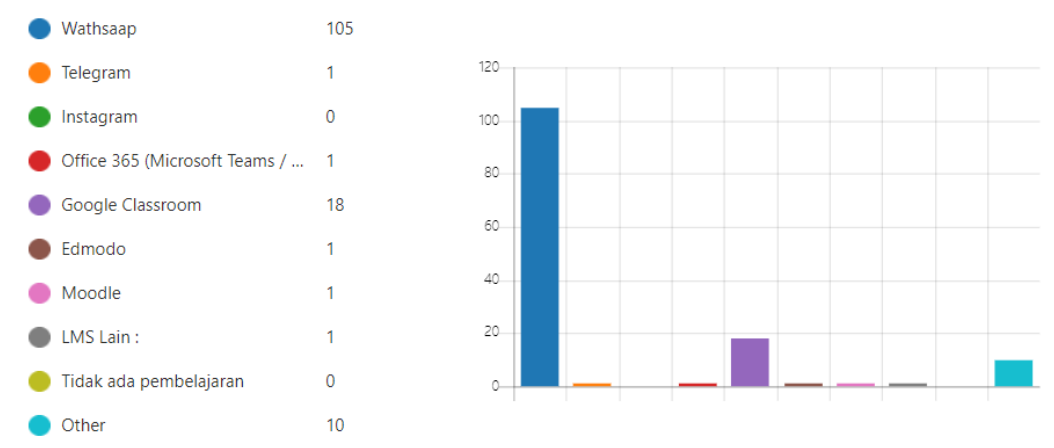

Figure 4: Media used to support online learning during the home learning program (BDR) 

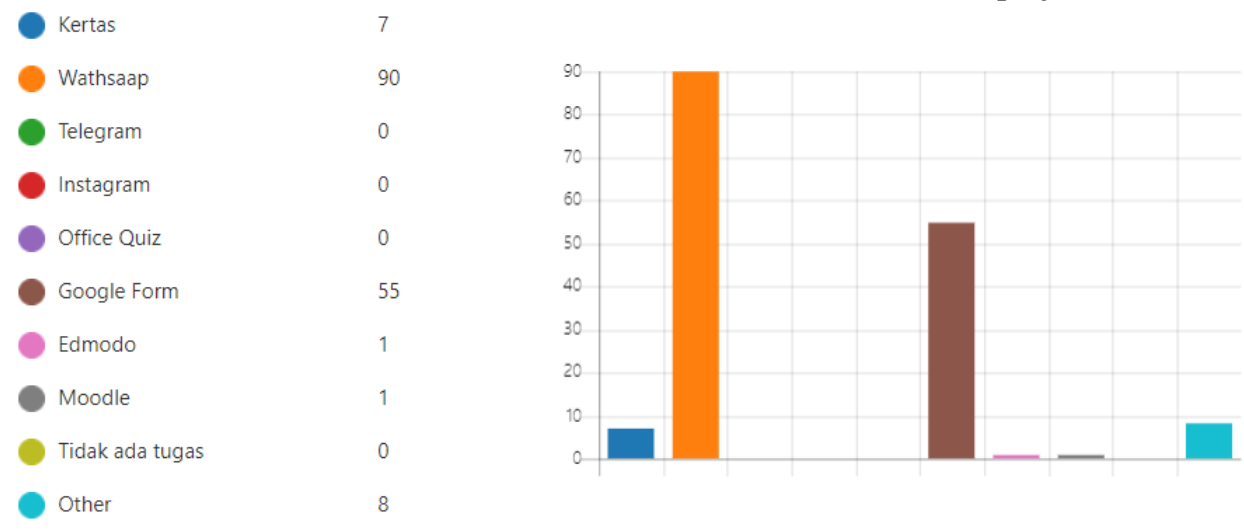

Figure 5: Media used to provide assignments during the home study program

Figures 4 and 5 provide an overview of how the learning implementation utilizes the technology during the home learning program. From these two figures, it revealed that the use of new technology was only for conveying messages to students, had not really made use of information technology as a real learning medium. In Figures 4 and 5, respondents might choose more than one media choice to convey material and evaluate learning to students. From the graphs above, the teachers' profile, literacy level and ICT literacy gaps, and ability to provide learning material online were obtained.

Through the process of collecting data, the questionnaire complemented by observations and interviews could identify other needs and constraints during the home learning program implementation. 1) The school did not yet have an online learning application (LMS). 2) Learning facilities owned by teachers and students were unequal. 3) Internet connection was unstable, especially in rural areas. 4) Teachers did not fully understand the online learning concept. 5) Skills in making learning media were lacking. 6) The teacher had never attended Microsoft quiz and mobile exam training for online assessment. 7) The teacher did not have an Office 365 account.

\section{Design and Development}

The learning design to improve the mathematics teachers' competence in online learning in the new normal era was in accordance with the needs analysis results, including 1) determining activity objectives and learning objectives, 2) determining appropriate learning strategies in the new normal era, 3) preparing lesson plans (RPP) and syllabus, 4) making learning modules in accordance with the lesson plans and syllabus, and 5) creating technical instructions for using the mobile exam application for online exams using smartphone media.

The objectives of the implementation in the form of training activities are 1) increasing the teachers' abilities and skills in developing learning materials based on information and communication technology, 2) providing an understanding of the distance learning concept, and 3) using the Microsoft quiz application and mobile exam for evaluation and online assessment. This research's main material was the use of the Microsoft quiz and the mobile exam application for online learning assessment and evaluation. Microsoft Form/Quiz is a simple and lightweight application that allows teachers to create surveys, quizzes, and polls easily. In educational institutions, it can be used to create quizzes, collect feedback from teachers and parents, or plan classroom and staff activities (Microsoft, 2020).

Some advantages of Microsoft quiz include: 1) there is already a question number; 2) various templates are available; 3) a random question and random answer feature are available; 4) a math feature is available for questions and answers in the form of math symbols; 5) timer features to limit the online exam time by date and time are available; 6) email notification feature is available; 7) answer suggestion feature is available when creating math questions; 8 ) students' scores or response can be 
downloaded immediately after completing the exam; 9) value adjustment feature is available when the new wrong answer key is known after the exam is over. Apart from the strengths mentioned above, there are several weaknesses and are still being developed by Microsoft, including 1) the serial number cannot be cut so that if the serial number starts with the identity, then the question number will start from the continuation number; 2 ) the random feature of questions only applies if the form is one section so that the identities are mixed with questions; 3 ) not yet providing a question bank so that all the available questions will appear to the students; 4) there is no question import facility from Ms. Word.

Besides, a mobile exam is an application that enables easy and practical online exams. With this application, students can carry out exams with their respective smartphones. According to Sarrayrih and llyas, the implementation of computer or smartphone-based exams should be able to prevent fraudulent acts that will be carried out by test takers, for example, looking for answers by browsing on the internet, sending answers to other participants via messenger, and viewing notes on their cellphones. In computer and cellphone-based exams, the software to be used to access the exam server must be completely safe and able to prevent the examinees from committing fraudulent acts (Sarrayrih \& llyas, 2013).

The mobile exam application is also an application based on the Android operating system used for online exams with smartphone media connected to the exam server. Some advantages of the online exam using the mobile exam application are that 1) the application can be downloaded for free via the Play store, 2) the application is very light and can be installed on Android at least version 5, 3) during the exam, the screen is full/full screen, 4) during the exam In progress, the smartphone cannot be used to open other applications so that students can focus on working on the questions displayed on the smartphone screen. Meanwhile, the weakness is that the mobile exam application cannot be accessed on operating systems other than Android until now.

Several activities were carried out at the development stage: 1) determining learning methods and strategies, 2) determining the media used, 3) refining the modules and technical instructions for application utilization, 4) conducting application trials in limited classes.

The trial implementation of the Microsoft quiz application and the mobile exam was conducted with 24 respondents from vocational schoolteachers. Before the trial, brief guidance was given on installing the mobile exam and trying to do an online exam using a smartphone. Respondents filled out questionnaires after online test trials. The questionnaire results of the online test trial are as follows:

Table 1. Trial of the Microsoft Quiz and Mobile Exam application

\begin{tabular}{lll}
\hline No & Aspects & Average \\
\hline 1. & Teachers are happy with the online exam model using smartphones. & 4,1 \\
2. & The questions displayed on the smartphone can be read properly. & 4,2 \\
3. & Internet connection is smooth. & 4,3 \\
4. & Teachers do not experience problems during online exams. & 4,1 \\
5. & Teachers prefer online exams with smartphones to on paper. & 4,2 \\
\hline
\end{tabular}

The application trial results showed that the Microsoft quiz and mobile exam applications got an average point above 4 , so they were feasible to be implemented in schools for assessment and evaluation of student learning outcomes. Of the 24 respondents, 13 people $(54 \%)$ stated that they used a personal data package while taking the online test trial, and 11 people $(46 \%)$ used the school Wi-Fi.

The use of the Microsoft quiz and the mobile exam application can be an alternative to paperbased exams and computer-based exams (CBT). The current situation and conditions make it possible 

to implement this application. Some things that can be taken into consideration can be seen in the following table.

Table 2. Comparison of assessment bases

\begin{tabular}{llrrc}
\hline No & \multicolumn{1}{c}{ Aspect } & Paper & Computer & Smartphone \\
\hline 1. & Question making & $\sqrt{ }$ & $\sqrt{ }$ & $\sqrt{ }$ \\
\hline 2. & Multiplication of questions & $\sqrt{ }$ & - & - \\
\hline 3. & Packing questions & $\sqrt{ }$ & - & - \\
\hline 4. & Answer sheet & $\sqrt{ }$ & - & - \\
\hline 5. & Exam Room & $\sqrt{ }$ & $\sqrt{ }$ & $\sqrt{ }$ \\
\hline 6. & Special room & $\sqrt{ }$ & $\sqrt{ }$ & - \\
\hline 7. & Invigilator & $\sqrt{ }$ & $\sqrt{ }$ & $\sqrt{ }$ \\
\hline 8. & Random questions and answers & - & $\sqrt{ }$ & $\sqrt{ }$ \\
\hline 9. & Quick assessment & - & $\sqrt{ }$ & $\sqrt{ }$ \\
\hline 10. & Internet network (LAN) & - & $\sqrt{ }$ & - \\
\hline 11. & Data/wifi package & - & - & $\sqrt{ }$ \\
\hline 12. & Local server & - & $\sqrt{ }$ & - \\
\hline 13. & Not limited by time and space & - & - & $\sqrt{ }$ \\
\hline
\end{tabular}

\section{Implementation and Evaluation}

The implementation of training and workshops took place entirely online using a combination of synchronous and asynchronous. The training that took place synchronously consisted of 1) virtual face to face with zoom meetings and meeting facilities in Microsoft Teams and 2) direct mentoring and guidance via WhatsApp groups or chat in Microsoft Teams. Meanwhile, the training that happened asynchronously comprised 1) doing assignments according to each school's needs and 2) independent practice through material or video tutorials uploaded on the Microsoft Teams channel.

Training on the use of the Microsoft quiz and mobile exam applications to improve teacher competence in online learning in the new normal era was held on July 18-25, 2020. The training was attended by 75 participants out of 109 who registered, came from junior high school representative mathematics teachers in Sragen Regency. The training was carried out online using meeting facilities from Microsoft Teams. All participants attended the training from their respective homes or schools, with laptops or PCs with cameras and internet connections. All participants who participated in the training got an Office 365 account to use during the training. Trainees entered virtual classes in Microsoft Teams; all the material and assignments were done through the virtual class. The training was carried out with a combination of synchronous and asynchronous. Synchronous meetings were conducted on the presentation of material using meeting facilities in Microsoft Teams. The materials given to participants during synchronous meetings included 1) the online learning concept; 2) introduction of Microsoft Teams as an online learning platform; 3) utilization of Microsoft form/quiz for online exams; 4) tricks to make math problems with questions and answers in the form of text, questions and answers in the form of equations, questions and answers in the form of graphs, questions and answers in the form of matrices, and questions and answers in the form of pictures. To strengthen the training results, they were given assignments and independent practice with assistance. In general, the training went well. It could be seen from the feedback results from the participants in providing an assessment on the evaluation questionnaire, as presented in the following table. 


\begin{tabular}{llc}
\hline No & \multicolumn{1}{c}{ Aspect } & Average \\
\hline & \multicolumn{1}{c}{ Training Program } & 4,6 \\
\hline 1. & Suitability of training materials with learning needs & 4,1 \\
\hline 2. & Achievement of training objectives & 3,9 \\
\hline 3. & Timeliness/implementation schedule & 4,1 \\
\hline 4. & New experiences gained & 4,1 \\
\hline & $\quad$ Resource Person & 4,2 \\
\hline 5. & Mastery of training materials & 4,5 \\
\hline 6. & Teaching ability & \\
\hline 7. & Interaction skills & 2,9 \\
\hline & Training Facilities & 3,8 \\
\hline 8. & Provision of internet connection/data package & 3,0 \\
\hline 9. & Supporting media and tools & 3,9 \\
\hline 10. & Smooth internet connection & 4,4 \\
\hline & Follow up plan & \\
\hline 11. & Implementation capability in schools & \\
\hline 12 & The need for assistance & \\
\hline
\end{tabular}

From the table above, each aspect had a reasonably high average and was in a good category. In the aspect of the training program, the average participant gave a good assessment, even at the point of the instrument regarding the suitability of the training material with current learning needs, the participants gave very good scores. It was because teachers very much needed the training material during this pandemic to provide online learning assessments and evaluations, which had never been done so far. From the interview results with several participants, this training provided new experiences in making assessment instruments for students online and in training, they were also given tricks on making math problems with equations, graphs, pictures, and matrices. The applications used were also not too difficult to learn.

In the aspect of the resource's ability to provide training, participants gave a good average rating. Conducting online training was the first experience; however, a good packaging combined between synchronous and asynchronous meetings coupled with the material uploaded in the virtual classroom accompanied by video tutorials becomes this training's advantage.

The training facility aspect received the lowest average rating from the participants. The training lacked support from the facilities, both from the committee and from the school. Online training required a reasonably large data package. Some participants carried out training from school, but some participated from home. The smooth operation of the internet connection was also an obstacle to conducting online training due to unstable connections and lost voices.

Further, the aspects of the follow-up plan after the training received high average scores. It exposed the participants' commitment to carry out the exam implementation using the Microsoft form and the mobile exam applications at the school after completing the training. Participants also hoped that there would be assistance during implementation in schools. Because the teachers were scattered in various areas that were quite far apart, participant mentoring was carried out using the WhatsApp group.

\section{CONCLUSION AND SUGGESTION}

The conclusions that could be drawn from this activity were that 1) the ADDIE model learning design was very appropriate to be applied to training activities for the use of Microsoft quiz and mobile 
exam applications, 2) through the process of needs analysis, designing, and developing training materials, the learning process in training could run smoothly good, effective, and efficient according to the teachers' needs in the new normal era, 3) the Microsoft quiz and mobile exam applications were feasible to be implemented for online assessment of learning outcomes and in accordance with current needs, and 4) internet connection for learning participants became an obstacle when implementing learning and online assessments.

Suggestions that can be recommended are 1) in the current new normal era, it is necessary to use information technology-based applications for the online learning and assessment implementation, 2) it is necessary to hold regular training to improve distance learning competencies, and 3) it needs infrastructure support for teachers and students for learning and assessment using online applications.

\section{REFERENCES}

Ardiansyah, A. A., \& Nana. (2020). Peran Mobile Learning Sebagai Inovasi Dalam Meningkatkan Hasil Belajar Siswa Pada Pembelajaran Di Sekolah. Indonesian Journal ff Educational Research and Review, 3 (1).

Arikunto. (2012). Dasar-dasar Evaluasi Pendidikan. Jakarta: Bumi Aksara.

Carey, D. a. (2015). Systematic Design of Instruction, The, 8th Edition. -: University of South Florida.

Dewi, W. A. (2020). DAMPAK COVID-19 TERHADAP IMPLEMENTASI PEMBELAJARAN DARING DI SEKOLAH DASAR. Jurnal IImu Pendidikan, 2 (1), 55-61.

G.Muruganantham. (2015). Developing of E-content package by using ADDIE Model. International Journal of Applied Research, 1(3): 52-54.

Gugah, S. (2020). Pendidikan Era Revolusi Industri 4.0 di Tengah Covid-19. Jakarta: https://ombudsman.go.id/artikel/r/artikel--pendidikan-era-revolusi-industri-40-di-tengah-covid-19.

Ika. (2020). Membedah Tantangan Pembelajaran Daring di Tengah Pandemi Covid-19. Yogyakarta: https://ugm.ac.id/id/berita/19552-membedah-tantangan-pembelajaran-daring-di-tengah-pandemi-covid19, diakses 31/10/2020.

Kemendikbud, S. (2020). SE tentang pedoman pelaksanaan belajar dari rumah selama darurat covid-19 di Indonesia. Jakarta: -

Ma, J. (2018). World Economic Forum. Davos, Swis: <https://www.liputan6.com/bisnis/read/3238241/jack-maubah-pendidikan-agarbersaing-dengan robot> diakses tgl 2 Oktober 2020.

Mendikbud. (2020). SE tentang pelaksanaan kebijakan pendidikan dalam masa darurat penyebaran corona virus diseases (Covid-19). Jakarta: -.

Mendiknas. (2007). Permendiknas nomor 16 tahun 2007 tentang Standar Kualifikasi Akademik dan Kompetensi Guru. Jakarta: -

Microsoft. (2020). Micorosft Form. -: https://support.microsoft.com/id-id/office/tanya-jawab-umum-tentangmicrosoft-forms-495c4242-6102-40a0-add8-df05ed6af61c.

Mutaqinah, R. T. (2020). Implementasi Pembelajaran Daring (Program BDR) Selama Pandemi Covid-19 di Jawa Barat. Jurnal Pendidikan Teknologi Informasi dan Komunikasi Volume 6, Nomor 2, September 2020, hal. $86-95$.

R. J. Stiggins. (1994). Student Centered Classroom Assessment. New York.

Rachmawati, \& Kurniawati, A. (2020). Pengembangan Instrumen Penilaian Tes Berbasis Mobile Online Pada Prodi Pendidikan Matematika. Jurnal Pendidikan Matematika, 4 (1), 46-63.

Sarjono. (2013). Membangun course e-learning berbasis moodle. Yogyakarta: UNY Press.

Sarrayrih, \& llyas. (2013). Challenges of Online Exam, Performances and Problems for Online University Exam. . International Journal of Computer Science Issues (IJCSI), 10(1), 439-445.

Sugiyono. (2017). Metode Penelitian Pendidikan (Pendekatan Kuantitatif, Kualitatif dan R\&D). Bandung: CV. 
Alfabeta.

http://jurnal.uns.ac.id/Teknodika

Suharwoto, G. (2020). Pembelajaran Online di Tengah Pandemi Covid-19, Tantangan yang Mendewasakan. Jakarta: https://pusdatin.kemdikbud.go.id/pembelajaran-online-di-tengah-pandemi-covid-19-tantanganyang-mendewasakan/.

Surani, D. (2019). Peran Teknologi Pendidikan dalan Pendidikan 4.0. Prosiding Seminar Nasional Pendidikan FKIP Universitas Ageng Tirtayasa, 2 (1), 456 - 469.

Zydney, J., \& Warner. (2016). Mobile Apps for Science Learning. Review of research. Elsevier Computers \& Education, 1-17.

How to cite: Sakroni \& Siswanto. (2021). Using Microsoft Quiz and Mobile Exam Applications to Improve Teacher Competence in Online Learning in the New Normal Era. Teknodika, 19 (1), 59 - 70 . DOI: https://doi.org/10.20961/teknodika.v19i1.46303 